\title{
PENGEMBANGAN MEDIA PEMBELAJARAN INTERAKTIF BERBASIS ECONOMIC LITERACY UNTUK MENINGKATKAN HASIL BELAJAR PADA MATA PELAJARAN EKONOMI SMP
}

\author{
Handriani Milladya Ginting ${ }^{1}$, R. Mursid ${ }^{2}$, Samsidar Tanjung ${ }^{3}$ \\ ${ }^{I}$ SMP Negeri 20 Medan, Sumatera Utara \\ ${ }^{2}$ FT Universitas Negeri Medan, Sumatera Utara \\ ${ }^{3}$ FIS Universitas Negeri Medan, Sumatera Utara \\ handrianiginting@gmail.com
}

\begin{abstract}
Abstrak: Penelitian ini bertujuank: (1) menghasilkan media pembelajaran interaktif yang layak digunakan untuk pembelajaran, (2) mengetahui keefektifan media pembelajaran interaktif yang dikembangkan pada pembelajaran ekonomi. Jenis penelitian ini adalah penelitian pengembangan menggunakan model Borg dan Gall dengan rancangan pembelajaran model Dick dan Carey. Hasil penelitian menunjukkan: (1) uji ahli pada kualifikasi sangat layak (95,33\%) (2) uji ahli desain pembelajaran kualifikasi sangat layak (91,25\%) (3) uji ahli rekayasa perangkat lunak dan desain grafis pada kualifikasi sangat layak (92,68\%), uji coba perorangan pada kualifikasi sangat layak (91,25\%) uji coba kelompok kecil pada kualifikasi sangat layak (93,59\%) uji coba lapangan pada kualifikasi sangat layak (93,33\%). Hasil hipotesis membuktikan bahwa terdapat perbedaan yang sangat signifikan antara hasil belajar siswa yang dibelajarkan dengan media pembelajaran interaktif berbasis economic literacy dengan hasil belajar siswa yang dibelajarkan dengan menggunakan buku teks. Hal ini ditunjukkan dengan hasil pengolahan data diperoleh $t$ hitung $>t$ tabel atau 5,785 > 1,667 atau terdapat perbedaan yang signifikan antara hasil belajar siswa yang dibelajarkan dengan menggunakan media pembelajaran interaktif dan menggunakan media pembelajaran buku teks.
\end{abstract}

Kata Kunci: media pembelajaran interaktif, buku teks, economic literacy, pelajaran ekonomi

Abstract: This study aims to: (1) produce interactive learning media that are feasible to use for learning, (2) find out the effectiveness of interactive learning media developed in economic learning. The type of this research is development research using the Borg and Gall model with the learning design model Dick and Carey. The results of the study showed: (1) expert testing in very feasible qualifications (95.33\%) (2) expert design tests of very feasible qualification learning (91.25\%) (3) software engineering and graphic design tests in very decent qualifications $(92.68 \%)$, individual trials in very decent qualifications (91.25\%) small group trials in very decent qualifications (93.59\%) field trials in qualifications are very feasible (93.33\%). The hypothesis results prove that there is a very significant difference between student learning outcomes learned by interactive learning media based on economic literacy and student learning outcomes learned by using textbooks. This is indicated by the results of data processing obtained t count $>t$ table or $5.785>1.667$ or there are significant differences between the learning outcomes of students who are taught using interactive learning media and using learning media textbooks.

Keywords: interactive learning media, textbooks, economic literacy, economic lessons

\section{PENDAHULUAN}

Mata pelajaran ekonomi memiliki peran penting dalam membentuk sikap rasional, terutama pada pengambilan keputusan ekonomi. Siswa yang mampu berfikir dan bersikap rasional dalam melakukan kegiatan ekonomi dapat dikatakan bahwa siswa tersebut telah melek ekonomi. Namun perilaku ekonomi siswa ternyata lebih banyak dipengaruhi oleh lingkungan dan teman. Salah satu pemicu perilaku yang kurang rasional adalah rendahnya pemahaman siswa terhadap aplikasi konsep ekonomi. Pelajaran ekonomi hanya memberikan seperangkat pengetahuan yang 
harus dihafalkan dan bukan diterapkan dalam kehidupan. Ekonomi sebagai salah satu mata pelajaran yang sudah diajarkan sejak SMP diharapkan mampu memberikan bekal kepada siswa untuk memiliki kecakapan di bidang ekonomi, sehingga siswa mampu menjadi pelaku ekonomi yang rasional. Namun secara empiris kecakapan siswa SMP dalam menggunakan ilmu ekonomi dalam kehidupan sehari-hari atau dalam berperilaku ekonomi, masih sangat jauh dari harapan dengan kata lain siswa belum mengetahui tentang melek ekonomi (economic literacy) yang baik. Hal ini dibuktikan dengan banyaknya perilaku remaja dalam melakukan tindakan ekonomi tidak didasarkan pertimbangan rasional, yaitu penerapan prinsip dan motif ekonomi dalam kegiatan konsumtif, namun lebih banyak dipengaruhi oleh lingkungannya.

Hasil observasi yang dilakukan oleh peneliti melalui tes angket terhadap 80 orang siswa kelas IV sebagai sampel dan 18 orang guru di SMP Negeri 20 Medan menunjukkan bahwa $100 \%$ siswa dan $95 \%$ dari guru- guru yang mengajar di SMP Negeri 20 Medan membutuhkan media pembelajaran dengan multimedia interaktif yang merupakan sumber belajar alternatif sebagai upaya dalam membantu proses pembelajaran yang lebih menarik untuk meningkatkan hasil belajar siswa.

Arsyad (2002:16) juga berpendapat bahwa agar proses belajar mengajar dapat berhasil dengan baik, siswa sebaiknya diajak untuk memanfaatkan semua alat inderanya. Guru berupaya untuk menampilkan rangsangan (stimulus) yang dapat diproses dengan berbagai inderanya. Semakin banyak alat indera yang digunakan untuk menerima dan mengelola informasi semakin besar pula kemungkinan informasi tersebut dapat dimengerti dan dapat dipertahankan dalam ingatan. Dengan demikian siswa dapat menerima dan menyerap dengan mudah dan baik pesan-pesan dalam materi yang disajikan.

Selanjutnya menurut Miarso (2011:41) menyatakan bahwa tidak ada suatu media yang terbaik untuk mencapai suatu tujuan pembelajaran, karena masing-masing jenis media memiliki kelebihan dan kekurangan. Oleh karena itu pemanfaatan kombinasi dua media atau lebih akan mampu membantu tercapainya tujuan pembelajaran. Lebih lanjut diungkapkan bahwa penggunaan media harus mempertimbangkan kecocokan media dengan karakteristik materi pelajaran yang disajikan dan bentuk kegiatan belajar yang dilaksanakan.

Kehadiran media pembelajaran interaktif dalam proses belajar mengajar telah membuat suasana yang berbeda dalam kelas, karena materi yang dulunya diajarkan dengan ceramah dan hanya monoton dapat divariasi dengan menampilkan tayangan berupa integrasi teks, suara, gambar bergerak dan video. Hal ini tentunya akan membuat siswa menjadi tertarik dengan materi yang diajarkan. Sujito (2008:11), dalam uji coba lapangan media interaktif terbukti mampu meningkatkan antusiasme siswa untuk terus belajar mandiri. Hal ini diperkuat oleh pendapat Kristiningrum (2007:9), multimedia yang dibuat bermanfaat untuk meningkatkan motivasi belajar siswa melalui pengembangan dan penciptaan sarana belajar, sumber belajar, serta menunjukkan kemajuan teknologi yang semakin pesat. CD Pembelajaran yang dihasilkan dapat dijadikan sebagai variasi sarana pembelajaran dan meningkatkan kreativitas serta memotivasi siswa untuk terus belajar supaya dapat memenuhi tuntutan perkembangan zaman.

Dari penjelasan tersebut, maka kehadiran media pembelajaran interaktif di sekolah saat ini merupakan hal yang berguna bagi proses pembelajaran. Pendapat keefektifan penggunaan media interaktif dalam proses pembelajaran di kelas juga dikemukakan oleh Dwiyono (2009:4), efektifitas pembelajaran terjadi karena siswa dapat melihat berbagai bentuk data baik gambar, teks, suara, gerak dan peragaan mengenai prosedur pelaksanaan tune up, sehingga memungkinkan siswa lebih menguasai materi pelajaran.

Perkembangan teknologi komputer terutama dalam bidang perangkat lunak mendukung dalam penerapannya sebagai media pembelajaran. Dengan komputer dapat disajikan media pembelajaran yang memuat materi pembelajaran secara tekstual, audio maupun visual. Salah satu perangkat lunak yang mendukung dalam mengembangkan media interaktif adalah macromedia flash 8.0. Andrisa (2007:22) Macromedia Flash 8.0 adalah software yang dipakai oleh para profesional WEB karena kemampuannya yang mengagumkan dalam menampilkan multimedia, gabungan antara grafis, animasi dan suara. Macromedia Flash mempunyai banyak keunggulan dibandingkan dengan software 
animasi lainnya diantaranya adalah program yang berorientasi objek, mampu mendesain gambar berbasis vektor, dapat dipergunakan sebagai software pembuat situs WEB, dan banyak keunggulan lainnya. Dengan beberapa kemudahan itulah macromedia flash 8.0 mendukung dalam penerapannya sebagai pengembang media pembelajaran berbentuk media interaktif.

Macromedia flash mempunyai banyak keunggulan dibandingkan dengan software animasi lainnya diantaranya adalah program yang berorientasi objek, mampu mendesain gambar berbasis vektor, dapat dipergunakan sebagai software pembuat situs WEB, dan banyak keunggulan lainnya. Perkembangan teknologi informasi dan komunikasi telah banyak digunakan dalam proses belajar mengajar, dengan satu tujuan mutu pendidikan akan selangkah lebih maju seiring dengan kemajuan teknologi. Perkembangan teknologi multimedia telah menjanjikan potensi besar dalam merubah cara seseorang untuk belajar, untuk memperoleh informasi, menyesuaikan informasi dan sebagainya. Multimedia juga menyediakan peluang bagi pendidik untuk mengembangkan teknik pembelajaran sehingga menghasilkan hasil yang maksimal dalam proses pembelajaran (Saroso, 2007).

\section{Belajar Dan Pembelajaran Ekonomi}

Menurut Rusman (2011:83) belajar adalah proses interaksi terhadap semua situasi yang ada di sekitar individu siswa. Belajar dapat dipandang sebagai proses yang diarahkan kepada pencapaian tujuan dan proses berbuat melalui berbagai pengalaman yang diciptakan oleh guru. Sedangkan menurut Sudjana (2000:28) belajar juga merupakan proses melihat, mengamati, dan memahami sesuatu.

Menurut Budiningsih (2005:34) teori belajar kognitif lebih mementingkan proses belajar daripada hasil belajarnya. Teori ini berpandangan bahwa belajar merupakan suatu proses internal yang mencakup ingatan, retensi, pengelolaan, informasi, emosi dan aspek-aspek kejiwaan lainnya.

Hamid (2009:19) berpendapat bahwa proses belajar kognitif termasuk mengatur stimulus yang diterima dan menyesuaikannya dengan struktur kognitif yang sudah ada atau diperoleh berdasarkan pengalaman-pengalaman sebelumnya sehingga terjadi perubahan dalam tingkah laku. Dengan kata lain, belajar adalah perubahan persepsi dan pemahaman.

Menurut Gagne salah satu defenisi belajar cukup sederhana namun mudah untuk diingat yaitu "Learning is relatively permanent change in behavior that result from past experience or purposeful instruction". Belajar adalah suatu perubahan perilaku yang relatif menentap yang dihasilkan dari pengalaman masa lalu ataupun dari pembelajaran yang bertujuan direncanakan. Pengalaman diperoleh individu dalam interaksinya dengan lingkungan, baik yang tidak direncankan maupun yang direncanakan sehingga menghasilkan perubahan yang bersifat relatif menetap.

Menurut Dimyati, dkk (2013:7) belajar merupakan tindakan dan perilaku siswa yang kompleks. Sebagai tindakan, maka belajar hanya dialami oleh siswa sendiri. Siswa adalah penentu terjadinya atau tidak terjadinya proses belajar.

Pembelajaran merupakan sebuah upaya yang dilakukan untuk memperoleh kompetensi pengetahuan, keterampilan, dan sikap yang diperlukan dalam melakukan suatu pekerjaan. Miarso (2011:144) memakai istilah pembelajaran sebagai aktivitas atau kegiatan atau kegiatan yang berfokus pada kondisi dan kepentingan pembelajaran (learner centered). Isitilah pembelajaran digunakan untuk menggantikan istilah "pengajaran" yang lebih bersifat sebagai aktivitas yang berfokus pada guru (teacher centered). Pembelajaran adalah proses yang sengaja dirancang untuk menciptakan terjadinya aktivitas belajar dalam diri individu. Dengan kata lain, pembelajaran merupakan suatu hal yang sengaja dirancang untuk mendukung terjadinya proses belajar internal dalam diri individu.

Seiring dengan pendapat di atas, Surya (2003:7) menyatakan bahwa: pembelajaran adalah suatu proses yang dilakukan oleh individu untuk memperoleh suatu perubahan perilaku yang baru secara keseluruhan, sebagai hasil dari pengalaman individu itu sendiri dalam interkasi dengan lingkungannya. Pendapat Rusman (2003:16) mengatakan bahwa pembelajaran merupakan interaksi komunikasi antara sumber belajar guru dan siswa.

Tujuan pembelajaran menurut Slavin (2000:23) adalah pernyataan mengenai keterampilan atau konsep yang diharapkan dapat dikuasai oleh peserta didik pada akhir periode-periode pembelajaran. Tujuan 
pembelajaran merupakan arah yang hendak dituju dari rangkaian aktivitas yang dilakukan dalam proses pembelajaran. Tujuan pembelajaran dirumuskan dalam bentuk perilaku kompetensi spesifik, aktual, dam terukur sesuai dengan yang diharapkan terjadi,dimiliki, atau dikuasai siswa setelah mengikuti kegiatan pembelajaran tertentu.

Supardi (2011:110) istilah ekonomi berasal dari bahasa Yunani, yaitu Oikos Namos atau Oikonomia. Secara bahasa, Oikos Namos atau Oikonomia sulit diterjemahkan. Tetapi orang-orang barat menerjemahkannya dengan Management of Housebold or Estate (tata laksana rumah tangga atau pemilikan). Seiring dengan perkembangan zaman dan ilmu pengetahuan muncul ilmu yang disebut ilmu ekonomi.

Case (2002:2) mengatakan ilmu ekonomi adalah studi tentang bagaimana individu dan masyarakat menentukan pilihan penggunaan sumber daya yang langka yang telah disediakan oleh alam dan generasi sebelumnya. Sejalan dengan itu, Mankiw (2013:4) mengemukakan bahwa ilmu ekonomi adalah ilmu yang mempelajari bagaimana masyarakat mengelola sumber daya mereka yang terbatas.

\section{Economic Literacy}

Menurut Agung Haryono (2012:4) economic literacy telah menjadi tema yang menarik untuk didiskusikan maupun diteliti sejak akhir dekade 1990-an. Di negara-negara maju sosialisasi disetarakan dengan melek huruf, dan melek teknologi. Hal ini dilakukan karena adanya kesadaran bahwa semua aspek kehidupan banyak terkait dengan masalah ekonomi. Masalah utama dalam ekonomi adalah adanya kelangkaan (scarcity), di mana masalah ini dihadapi oleh semua anggota masyarakat, baik orang kaya maupun miskin. Disadari atau tidak ekonomi telah berdampak pada sendi kehidupan masyarakat. Terkait dengan masalah pendapatan misalnya, ada beberapa masalah yang harus dihadapi antara lain: (1) bagaimana pendapatan masyarakat, (2) seberapa besar pendapatan tersebut, (3) bagaimana ketersediaan barang dan jasa yang dapat dibeli masyarakat, (4) dan bagaimana menginvestasikan pendapatan untuk masa depan (Brenner,1999).

Agung Haryono (2012:4) economic literacy adalah kemampuan untuk mengidentifikasi masalah-masalah ekonomi, penyusunan alternatif pemecahan dengan mempertimbangkan benefit dan cost. Pengukuran economic literacy yang sudah dikembangkan di Amerika lebih banyak menekankan pada aspek pengetahuan, sedangkan pada aspek sikap belum banyak terungkap. Unsur sikap yang dominan dalam ekonomi adalah rasional dan moral, seperti diungkapkan oleh Sayer (2004:2) bahwa ilmu ekonomi dan praktek kegiatan ekonomi sangat dipengaruhi oleh norma, adat, kebiasaan, nilainilai dan sistem ekonomi yang dianut masyarakat. Sehingga economic literacy sebenarnya dimiliki oleh semua masyarakat yang menganut Sistem Ekonomi Liberal, Sosial, Pancasila atau Ekonomi Islam. Meskipun awal pengembangan konsep economic literacy dilakukan di negara yang menganut Ekonomi Liberal.

Sedangkan menurut NCEE (2003) mengembangkan kriteria economic literacy menjadi 20 indikator yang telah dikembangkan dalam bentuk test untuk mengukur tingkat economic literacy masyarakat. Keduapuluh indikator tersebut adalah: (1) mampu menganalisis perubahan permintaan barang; (2) mampu menjelaskan peran wirausaha; (3) mampu menganalisis pengaruh tingkat bunga terhadap kecenderungan menabung masyarkat; (4) mampu menjelaskan pendapatan individu; (5) mampu menjelaskan pendapatan nasional; (6) mampu menganalis perubahan penawaran dan perubahan permintaan; (7) mampu menganalisis dampak kebijakan perdangan internasional; (8) mampu menganalisis dampak kebijakan pemerintah dalam penetapan harga; (9) mampu menjelaskan peranan pelaku ekonomi; produsen, konsumen dan pemerintah dalam perekonomian; (10) mampu menjelaskan manfaat dari perdagangan internasional; (11) mampu menganalisis dampak perubahan permintaan/penawaran terhadap harga barang (12) mampu menjelaskan penggunaan sumberdaya yang terbatas; (13) mampu menjelaskan peran pasar modal dalam perekonomian; (14) mampu menganalisis cost dan benefit dari transaksi ekonomi; (15) mampu menganalisis cost dan benefit dari pengambilan keputusan; (16) mampu menjelaskan peranan pemerintah dalam perekonomian; (17) mampu menjelaskan anggaran pendapatan dan belanja negara; (18) mampu menganalisis dampak inflasi; (19) mampu menganalisis 
pengembangan industri;

mampu

menjelaskan fungsi uang.

Makna kemampuan (ability)

mengindikasikan bahwa pemahaman economic literacy dihasilkan melalui proses belajar yang berkesinambungan sehingga dapat dikatakan bahwa literasi keuangan merupakan bagian juga economic literacy. Dipertajam lagi oleh Peter (2012:9) bahwa economic literacy adalah ketrampilan hidup (life skill) yang harus dimiliki oleh siapa saja untuk membuat keputusan ekonomi yang tepat. Oleh karena itu, economic literacy dapat diaplikasikan untuk konteks individu maupun rumah tangga. Seperti dilansir oleh Mathews (1999:3) bahwa manfaat mempelajari economic literacy yakni memahami pengaruh inflasi pada nilai tukar uang, menjadi penabung, investor, serta menjadi investor yang lebih cerdas, dan yang terutama adalah bagaimana economic literacy dapat memfasilitasi interaksi antara manfaatmanfaat apabila meningkatkan economic literacy.

\section{Media Pembelajaran}

Kata media berasal dari bahasa Latin medius yang secara harfiah berarti 'tengah', 'perantara' atau 'pengantar'. Dalam bahasa Arab, media adalah perantara atau pengantar pesan dari pengirim kepada penerima pesan. Gerlach \& Ely (1971) mengatakan bahwa media pembelajaran apabila dipahami secara garis besar adalah manusia, materi atau kejadian yang membangun kondisi yang membuat siswa mampu memperoleh pengetahuan, keterampilan, atau sikap. Secara khusus pengertian media dalam proses belajar cenderung diartikan sebagai alat-alat grafis, photographis, atau elektronis untuk menangkap, memproses, dan menyusun kembali informasi visual atau verbal.

AECT (Association of Education and Communication Technology, 1977) memberi batasan tentang media sebagai segala bentuk dan saluran yang digunakan untuk menyampaikan pesan atau informasi. Menurut Heinich mengemukakan istilah medium sebagai perantara yang mengantar informasi antara sumber dan penerima. Apabila media itu membawa pesan-pesan atau informasi yang bertujuan instruksional atau mengandung maksud-maksud pengajaran maka media itu disebut sebagai media pembelajaran.
Menurut Daryanto (2012:17) terdapat sembilan kelompok media, yaitu: visual diam, film, televisi, obyek tiga dimensi, rekaman, pelajaran terprogram, demonstrasi, buku teks cetak, dan sajian lisan. Sedangkan menurut Gerlach \& Ely, media dikelompokkan berdasarkan ciri-ciri fisiknya atas delapan kelompok, yaitu berdasarkan benda sebenarnya, presentasi verbal, presentasi grafis, gambar diam, gambar bergerak, rekaman suara, pengajaran terprogram, dan simulasi.

\section{Media Pembelajaran Interaktif}

Dalam merencanakan dan melaksanakan aktivitas pembelajaran, setiap guru dituntut dapat mempersiapkan dan memfungsikan segala unsur yang menunjang kelancaran proses pembelajaran agar dapat berjalan dengan efektif dan efisien. Sebagai salah satu unsur dalam menunjang pembelajaran, guru dituntut agar mengetahui dan merancang pemakaian media pembelajaran serta dapat mengetahui fungsi dan kegunaan media tersebut. Sadiman (2003:189) fungsi atau kegunaan media antara lain: (1) membuat konkrit konsep yang abstrak, (2) membawa objek yang berbahaya atau sukar didapat ke dalam lingkungan belajar. (3) menampilkan objek yang terlalu besar, (4) menampilkan objek yang tidak dapat diamati dengan mata telanjang, (5) mengamati gerakan yang terlalu cepat, (6) memungkinkan siswa berinteraksi langsung dengan lingkungannya, (7) memungkinkan kesegaran pengamatan dan persepsi bagi pengamatan belajar siswa, (8) membangkitkan motivasi belajar, (9) meyajikan informasi belajar secara konsisten dan dapat diulangi maupun disimpan menurut kebutuhan, (10) menyajikan pesan atau informasi belajar secara serempak, membatasi batasan waktu maupun ruang, dan (11) mengontrol arah maupun kecepatan belajar siswa.

Secara singkat dapat dikatakan bahwa dasar pemilihan media adalah dapat terpenuhinya kebutuhan dan tercapainya tujuan pembelajaran, jika sesuai dengan kebutuhan dan tujuan maka media tersebut tidak dapat digunakan Ada beberapa kriteria umum yang digunakan dalam penggunaan media, yaitu: (1) kesesuaian dengan tujuan, (2) kesesuaian dengan materi pembelajaran, (3) kesesuain dengan karakteristik pembelajaran atau siswa, (4) kesesuaian dengan teori, (5) kesesuaian dengan gaya belajar siswa, (6) kesesuain 
dengan kondisi lingkungan, fasilitas pendukung, dan waktu yang tersedia. Disamping kriteria umum yang digunakan, Rudi Susilana (2009:73) juga mengemukakan dalam pengunaan media, ada kriteria khusus lainnya dalam memilih media pembelajaran yang tepat dapat di rumuskan dalam satu kata ACTION, yaitu:

1. ACCESS: Kemudahan akses menjadi pertimbangan pertama dalam memili media. Apakah media yang diperlukan tersedia, mudah, dan dapat dimanfaatkan oleh siswa?

2. COST: Biaya juga harus dipertimbangkan. Banyak jenis media yang dapat menjadi pilihan kita, pada umumnya media itu harus kita hitung dengan aspek manfaatnya.

3. TECHNOLOGY: Mungkin saja kita tertarik pada satu media tertentu. Tapi kita perlu perhatikan apakah teknologinya tersedia dan mudah digunakannya?

4. INTERACTIVITY: Media yang baik adalah yang dapat memunculkan komunikasi dua arah atau interaktivitas.

5. ORGANIZATION: Pertimbangan yang juga penting adalah dukungan organisasi.

6. NOVELITY: Kebaruan dari media yang anda pilih juga harus menjadi pertimbangan. Media yang lebih baru biasnya lebih baik dan lebih menarik bagi siswa.

Menurut Sagala (2011:61) pembelajaran interaktif mempunyai dua karakteristik yaitu: (1) dalam proses pembelajaran melibatkan proses mental siswa secara maksimal, bukan hanya menuntut siswa sekedar mencatat, akan tetapi menghendaki aktivitas siswa dalam proses berpikir, (2) dalam pembelajaran membangun suasana dialogis dan proses tanya jawab terus menerus yang diarahkan untuk memperbaiki dan meningkatkan kemampuan siswa untuk memperoleh pengetahuan yang mereka konstruksi sendiri.

Arsyad (2002:23) mengelompokkan media pembelajaran interaktif merupakan kelompok pilihan media teknologi mutakhir. Media teknologi mutakhir sendiri dibedakan menjadi (1) media berbasis telekomunikasi, misal teleconference, kuliah jarak jauh, dan (2) media berbasis mikroprosesor, misal computerassistted instruction, permainan komputer, sistem tutor intelejen, interaktif, hypermedia, dan compact (video) disc.

\section{Pengembangan Media Pembelajaran Interaktif}

Dalam pengembangan media pembelajaran interaktif pada mata pelajaran ekonomi digunakan model pengembangan produk Borg \& Gall (1983:775), dan untuk mengembangkan recana pembelajarannya dipadukan dengan model pengembangan pembelajaran model Dick \& Carey (2005:1). Model pengembangan Borg \& Gall (1983:776) memuat panduan sistematika langkah-langkah yang dilakukan oleh peneliti agar produk yang dirancangnya mempunyai standar kelayakan. Dengan demikian, yang diperlukan dalam pengembangan ini adalah rujukan tentang prosedur produk yang akan dikembangkan. Prosedur penelitian pengembangan pada dasarnya terdiri dari dua tujuan utama, yaitu: (a) mengembangkan produk, dan (b) menguji keefektifan produk dalam mencapai tujuan. Tujuan pertama disebut sebagai fungsi pengembang sedangkan tujuan kedua disebut sebagai validasi. Dengan demikkian, konsep penelitian pengembangan lebih tepat diartikan sebagai upaya pengembangan yang sekaligus disertai dengan upaya validasinya.

Rumusan masalah dalam penelitian ini adalah sebagai berikut: (1) Apakah pengembangan media interaktif berbasis economic literacy dengan menggunakan macromedia flash pada mata pelajaran ekonomi sudah layak untuk siswa?; (2) Apakah pembelajaran ekonomi dengan menggunakan media interaktif berbasis economic lietarcy menggunakan macromedia flash lebih efektif daripada pembelajaran dengan menggunakan media konvensional (buku teks) terhadap hasil belajar kosakata siswa?

\section{METODE}

Penelitian ini dilaksanakan di SMP Negeri 20 Medan pada siswa kelas VII semester genap. Populasi dalam penelitian ini adalah seluruh siswa kelas VII SMP Negeri 20 Medan yang berjumlah 8 kelas yaitu VII-1, VII-2, VII3, VII-4, VII-5, VII-6, VII-7, VII-8 dengan jumlah keseluruhan 320 siswa. Dari seluruh populasi ditentukan sampel yaitu VII-2 sebagai kelas eksperimen, VII-4 sebagai kelas kontrol. Pengambilan sampel dilakukan dengan random 
sampling. Tahap pelaksanaan penelitian ini dilaksanakan pada semester genap dengan sampel yang terdiri dari satu kelas berjumlah 40 orang peserta didik.

Model pengembangan yang digunakan dalam pengembangan media pembelajaran ini adalah model pengembangan Borg and Gall (1983:775) yang dipadu dengan model pengembangan pembelajaran model Dick and Carey (2005:1). Adapun langkah-langkah dari tahapan pengembangannya adalah sebagai berikut ini.

1. Melakukan penelitian pendahuluan, yang meliputi: (1) identifikasi kebutuhan pembelajaran dan menentukan standar kompetensi mata pelajaran, (2) melakukan analisis pembelajaran, (3) mengidentifikasi karakteritik dan perilaku awal peserta didik, dan (4) menulis kompetensi dasar dan indikatornya.

2. Menulis tes acuan patokan : menyusun strategi pembelajaran yang diwujudkan dalam bentuk silabus dan satuan pembelajaran. (1) mengembangkan materi pembelajaran, dan (2) pembuatan desain software, yang meliputi : pembuatan naskah, dan pembuatan storyboard.

3. Pengumpulan bahan, yang meliputi: (1) pembuatan dan pengumpulan gambar (image) dan animasi, (2) perekaman dan pengumpulan audio

4. Mengembangkan dan membuat media pembelajaran interaktif

5. Review dan uji coba produk.

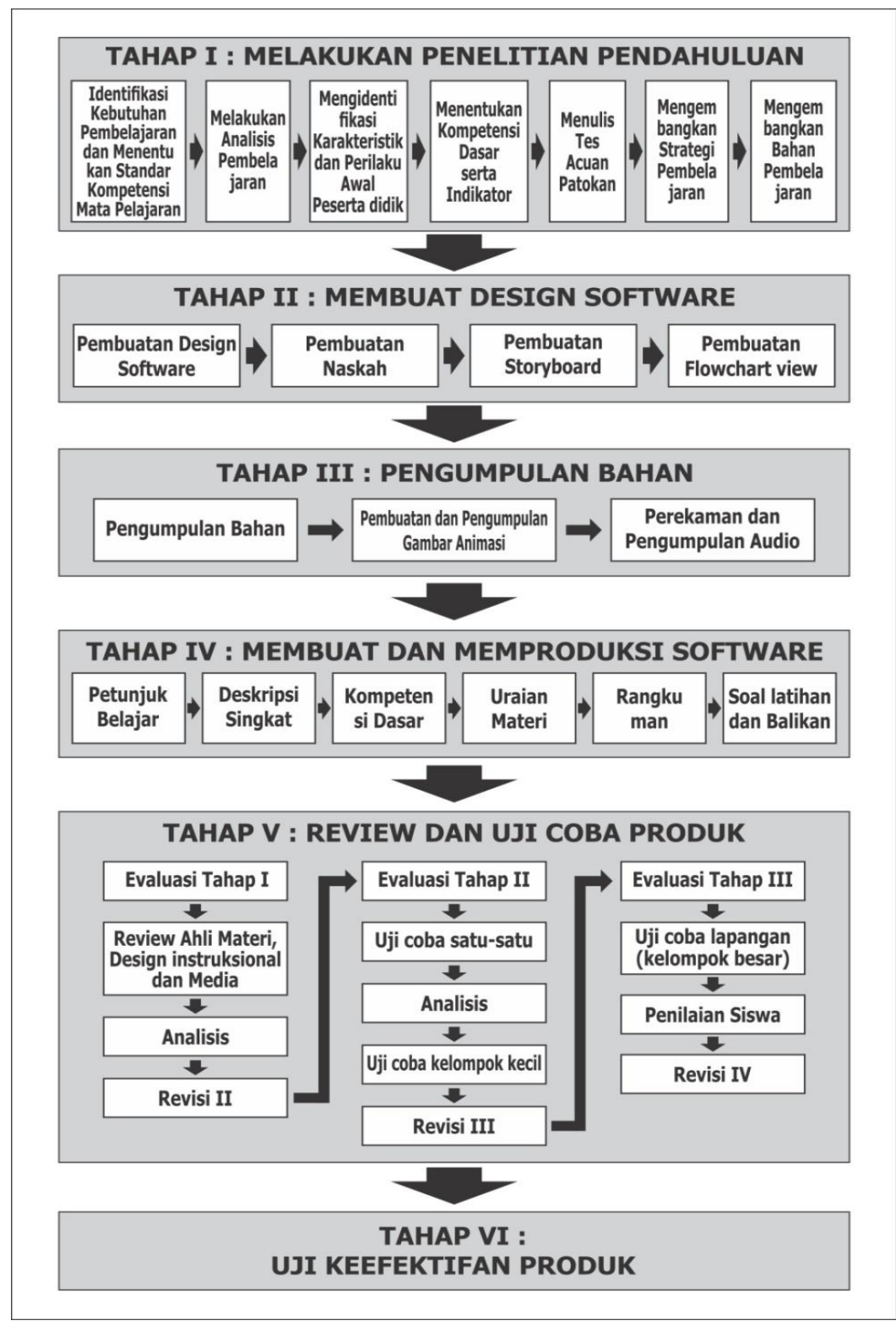

Gambar 1. Tahapan Penelitian 


\section{Tahap Uji Coba Produk 1. Desain Uji Coba}

Desain uji coba tahap-tahapnya adalah sebagai berikut: (1) Validasi ahli materi ekonomi; (2) Validasi ahli media; (3) Validasi ahli desain instruksional; (4) Analisis konseptual; (5) Revisi pengembangan (tahap I), berdasarkan penilaian yang berupa masukan, kritik atau saran dari ahli materi, ahli media dan ahli desain instruksional untuk dilakukan perbaikan; (6) Uji coba terhadap peserta didik (perorangan dan kelompok kecil). Penilaian terhadap program ini berdasarkan angket yang telah diisi oleh 3 peserta didik ( uji satu- satu ) dan 9 orang peserta didik (uji coba kelompok kecil); (7) Analisis konseptual dan produk; (8) Revisi produk (tahap II); (9) Uji coba lapangan terhadap peserta didik; (10) Penilaian mengenai daya tarik dan kelayakan produk; (11) Analisis empirik (tahap III); (12) Revisi kecil; (13) Penilaian mengenai daya tarik dan kelayakan produk; (14) Analisis empirik (tahap IV); (15) Revisi kecil; dan (16) Uji efektivitas produk

\section{Teknik Analisis Data}

Analisis data dalam penelitian ini menggunakan analisis deskriptif kuantitatif. Semua data terkumpul dianalisis dengan teknik statistik deskriptif yang secara kuatitatif dipisahkan menurut kategori untuk mempertajam penilaian kesimpulan. Data-data yang terkumpul dapat dikelopokkan menjadi dua yaitu data kualitatif yang berbentuk kata atau simbol dan data kuantitatif yang berbentuk angka-ngka. Data kualitatif kan dianalisis secara logis dan bermakna, sedangkan data kuantitatif akan dianalisis dengan deskriptif persentase. Hasil analisis deskriptif ini digunakan untuk menentukan tingkat keefektifan produk multimedia interaktif ini.
Keefektifan dan daya tarik produk diketahui melalui hasil analisis kegiatan uji coba yang dilaksanakan melalui beberapa tahapan yaitu: 1) review oleh ahli materi, ahli media dan ahli desain grafis, dan 2) uji coba lapangan. Data kuantitatif berupa pernyataan sangat layak, layak, sedang, kurang layak dan sangat tidak layak sesuai diubah menjadi data kuantitaif dengan skala nilai 1 sampai 5 .

Untuk membuktikan hipotesis standar kelayakan dan keefektifan produk dilakukan pengujian keefektifan produk yang dikembangkan dan uji-t. Analisis data pada penelitian ini menggunakan teknik analisis kuantitatif.

Untuk melihat keefektifan media interaktif yang dieksperimenkan digunakan rumus perhitungan efektifitas berikut (Sugiono, $2011: 411-418$ ) : $\mathrm{X}=\frac{\text { Jumlah skor yang diperoleh }}{\text { jumlah skor ideal seluruh item }} \times 100 \%$

Tabel 1. Kriteria Penilaian

\begin{tabular}{ccc}
\hline Nilai & Kriteria & Persentase \\
\hline A & Sangat layak & $81 \% \leq \times \leq 100 \%$ \\
B & Layak & $61 \% \leq x \leq 80 \%$ \\
C & Sedang & $41 \% x \leq 60 \%$ \\
D & Kurang layak & $21 \% \leq x \leq 40 \%$ \\
E & Sangat tidak layak & $0 \% \leq x \leq 20 \%$ \\
\hline
\end{tabular}

$\mathrm{X}=$ Skor Empiris

\section{HASIL PENELITIAN}

Uji coba lapangan dilakukan terhadap siswa yang terdiri dari 40 siswa yakni kelas VII-2. Uji coba lapangan menghasilkan datadata yang nantinya akan mengukur kelayakan dari produk yang dikembangkan, serta untuk mengetahui bagaimana manfaat produk tersebut bagi pemakainya. Hasil evaluasi terhadap media pembelajaran pada aspek kualitas materi pembelajaran.

Tabel 2. Skor Penilaian Media Pembelajaran Interaktif di SMP Negeri 20 Medan kelas VII pada Aspek Kualitas Materi Pembelajaran

\begin{tabular}{|c|c|c|c|c|c|c|}
\hline \multirow{2}{*}{ No } & \multirow{2}{*}{ Indikator Penilaian } & \multicolumn{3}{|c|}{ Skor } & \multirow{2}{*}{ Jumlah } & \multirow[t]{2}{*}{ Kriteria } \\
\hline & & $\begin{array}{lll}1 & 2 & 3\end{array}$ & 4 & 5 & & \\
\hline 1 & Kesesuaian materi & & 11 & 29 & $94,50 \%$ & Sangat Layak \\
\hline 2 & Kejelasan petunjuk belajar & & 13 & 27 & $93,50 \%$ & Sangat Layak \\
\hline 3 & Kemudahan memahami kalimat pada teks & & 14 & 26 & $93,00 \%$ & Sangat Layak \\
\hline 4 & Kemudahan memahami pembelajaran & & 13 & 27 & $93,50 \%$ & Sangat Layak \\
\hline 5 & Ketepatan urutan penyajian & & 13 & 27 & $93,50 \%$ & Sangat Layak \\
\hline 6 & Kecukupan latihan & & 15 & 25 & $92,50 \%$ & Sangat Layak \\
\hline 7 & Kejelasan umpan balik & & 14 & 26 & $93,00 \%$ & Sangat Layak \\
\hline 8 & Bantuan belajar dengan program & & 14 & 26 & $93,00 \%$ & Sangat Layak \\
\hline & Rata-rata & & & & $93,31 \%$ & Sangat Layak \\
\hline
\end{tabular}


Tabel 2 menunjukkan hasil tanggapan siswa pada aspek kualitas materi pembelajaran untuk uji coba lapangan dan keseluruhannya dalam kriteria "Sangat Layak".

Hasil evaluasi terhadap media pembelajaran pada aspek kualitas teknis atau tampilan menunjukkan hasil tanggapan siswa pada aspek kualitas teknis atau tampilan untuk uji coba lapangan dan keseluruhan kriteria dinilai "Sangat Layak". Hasil evaluasi terhadap media pembelajaran pada aspek kualitas teknis atau tampilan dapat dilihat pada Tabel 3.

Tabel 3. Skor Penilaian Media Pembelajaran Interaktif Uji Coba Lapangan Pada Aspek Kualitas Teknis atau Tampilan

\begin{tabular}{|c|c|c|c|c|c|c|c|c|}
\hline \multirow{2}{*}{ No } & \multirow{2}{*}{ Indikator Penilaian } & \multicolumn{5}{|c|}{ Skor } & \multirow{2}{*}{ Rata-rata } & \multirow{2}{*}{ Kriteria } \\
\hline & & 1 & 2 & 3 & 4 & 5 & & \\
\hline 1 & Keindahan tampilan layar & & & & 13 & 27 & $93,50 \%$ & Sangat Layak \\
\hline 2 & Keterbacaan teks & & & & 13 & 27 & $93,50 \%$ & Sangat Layak \\
\hline 3 & Kualitas gambar dan animasi & & & & 14 & 26 & $93,00 \%$ & Sangat Layak \\
\hline 4 & Komposisi warna & & & & 15 & 25 & $92,50 \%$ & Sangat Layak \\
\hline 5 & Navigasi & & & & 12 & 28 & $94,00 \%$ & Sangat Layak \\
\hline 6 & Daya dukung musik & & & & 12 & 28 & $94,00 \%$ & Sangat Layak \\
\hline 7 & Interaksi & & & & 14 & 26 & $93,00 \%$ & Sangat Layak \\
\hline & Rata-rata & & & & & & $93,36 \%$ & Sangat Layak \\
\hline
\end{tabular}

Hasil penilaian uji coba lapangan terhadap aspek kualitas materi pembelajaran pada media pembelajaran interaktif telah dirangkum pada Tabel 3. Hasil tanggapan siswa menyatakan bahwa untuk aspek kualitas materi pembelajaran pada uji coba lapangan menunjukkan 40 orang (100\%) menyatakan "Sangat Layak". Hasil tanggapan siswa tersebut dapat dilihat pada Tabel 4.

Tabel 4. Tingkat Kecenderungan Penilaian Terhadap Aspek Kualitas Materi Pembelajaran Media Pembelajaran Interaktif Pada Uji Coba Lapangan

\begin{tabular}{clccc}
\hline No. & \multicolumn{1}{c}{ Kategorisasi } & Persentase & Frekuensi & Persentase \\
\hline 1 & Sangat Layak & $81 \% \leq \mathrm{x} \leq 100 \%$ & 40 & $100,00 \%$ \\
2 & Layak & $61 \% \leq \mathrm{x}<80 \%$ & 0 & $0,00 \%$ \\
3 & Cukup Layak & $41 \% \leq \mathrm{x}<60 \%$ & 0 & $0,00 \%$ \\
4 & Kurang Layak & $21 \% \leq \mathrm{x}<40 \%$ & 0 & $0,00 \%$ \\
5 & Sangat Kurang Layak & $0 \% \leq \mathrm{x}<20 \%$ & 0 & $0,00 \%$ \\
\hline \multicolumn{2}{c}{ Jumlah } & & 40 & $100,00 \%$ \\
\hline
\end{tabular}

Hasil tanggapan siswa pada uji coba menyatakan "Sangat Layak" tampak pada Tabel lapangan pada aspek kualitas teknis atau 5. tampilan menunjukkan bahwa 80 orang $(100 \%)$

Tabel 5. Tingkat Kecenderungan Penilaian Terhadap Aspek Kualitas Teknis/Tampilan Media Pembelajaran Interaktif

\begin{tabular}{clccc}
\hline No. & \multicolumn{1}{c}{ Kategorisasi } & \multicolumn{1}{c}{ Persentase } & Frekuensi & Persentase \\
\hline 1 & Sangat Layak & $81 \% \leq \times 100 \%$ & 40 & $100,00 \%$ \\
2 & Layak & $61 \% \leq \mathrm{x}<80 \%$ & 0 & $0,00 \%$ \\
3 & Cukup Layak & $41 \% \leq \mathrm{x}<60 \%$ & 0 & $0,00 \%$ \\
4 & Kurang Layak & $21 \% \leq \mathrm{x}<40 \%$ & 0 & $0,00 \%$ \\
5 & Sangat Kurang Layak & $0 \% \leq \mathrm{x}<20 \%$ & 0 & $0,00 \%$ \\
\hline \multicolumn{2}{r}{ Jumlah } & & 40 & $100,00 \%$ \\
\hline
\end{tabular}


Pada uji coba lapangan ternyata secara umum siswa menyatakan media pembelajaran yang dikembangkan Sangat Layak, dan tidak terdapat masalah yang harus diperbaiki.

\section{Analisis Data Hasil Validasi Produk Awal}

Hasil penilaian oleh ahli materi, ahli desain pembelajaran dan ahli rekayasa perangkat lunak pada setiap aspek penilaian secara keseluruhan ditentukan oleh skor ratarata pada kategorinya masing-masing. Hasil penilaian tersebut kemudian dianalisis untuk menentukan layak tidaknya, dikembangkan media pembelajaran interaktif. Adapun persentase rata-rata dari hasil penilaian ahli materi, ahli desain pembelajaran dan ahli rekayasa perangkat lunak akan diuraikan sebagai berikut.

\section{Analisis Data hasil Evaluasi Ahli Materi}

Tabel 6. Persentase Rata-Rata Hasil Penilaian Terhadap Media Pembelajaran Interaktif Oleh Ahli Materi

\begin{tabular}{|c|c|c|c|}
\hline No. & Kategori & $\begin{array}{c}\text { Persentase } \\
\text { Rata-rata }\end{array}$ & Kriteria \\
\hline \multirow{8}{*}{$\begin{array}{l}1 \\
2 \\
3\end{array}$} & Aspek materi & & Sangat \\
\hline & pembelajaran & $95,00 \%$ & Layak \\
\hline & Aspek strategi & & Sangat \\
\hline & pembelajaran & $96,00 \%$ & Layak \\
\hline & Aspek sistem & & \\
\hline & penyampaian & & Sangat \\
\hline & pembelajaran & $95,00 \%$ & Layak \\
\hline & Rata-rata & $95,33 \%$ & $\begin{array}{l}\text { Sangat } \\
\text { Layak }\end{array}$ \\
\hline
\end{tabular}

\section{Analisis Data Hasil Evaluasi Ahli Desain Pembelajaran}

Tabel 7. Persentase Rata-Rata Hasil Penilaian Terhadap Media Pembelajaran Interaktif Mata Pelajaran Ekonomi Oleh Ahli Desain Pembelajaran

\begin{tabular}{|c|c|c|c|}
\hline No. & Kategorisasi & $\begin{array}{c}\text { Persentase } \\
\text { Rata-rata }\end{array}$ & Kriteria \\
\hline & Kualitas desain & & Sangat \\
\hline 1 & pembelajaran & $92,50 \%$ & Layak \\
\hline \multirow[t]{2}{*}{2} & Kualitas desain & $92,50 \%$ & Sangat \\
\hline & informasi & & Layak \\
\hline \multirow[t]{2}{*}{3} & Kualitas desain & & Sangat \\
\hline & interaksi & $90,00 \%$ & Layak \\
\hline \multirow[t]{2}{*}{4} & Kualitas desain & & Sangat \\
\hline & presentasi & $90,00 \%$ & Layak \\
\hline & & & Sangat \\
\hline & Rata-rata & $91,25 \%$ & Layak \\
\hline
\end{tabular}

\section{Analisis Data Hasil Evaluasi Ahli Perangkat} Lunak

Tabel 8. Persentase Rata-Rata Hasil Penilaian Terhadap Media Pembelajaran Interaktif Mata Pelajaran Ekonomi Oleh Ahli Perangkat Lunak

\begin{tabular}{clcl}
\hline No. & Kategorisasi & $\begin{array}{c}\text { Persentase } \\
\text { Rata-rata }\end{array}$ & Kriteria \\
\hline 1 & $\begin{array}{l}\text { Kualitas } \\
\text { Pemograman }\end{array}$ & $92,50 \%$ & $\begin{array}{l}\text { Sangat } \\
\text { Layak }\end{array}$ \\
\hline 2 & $\begin{array}{l}\text { Kualitas Teknis } \\
\text { atau Tampilan }\end{array}$ & $92,86 \%$ & $\begin{array}{l}\text { Sangat } \\
\text { Layak }\end{array}$ \\
\hline & Rata-rata & $92,68 \%$ & $\begin{array}{l}\text { Sangat } \\
\text { Layak }\end{array}$ \\
\hline
\end{tabular}

\section{Analisis Data Hasil Uji Coba Tahap II Uji Coba Perorangan}

Tabel 9 berikut menunjukkan persentase rata-rata hasil penilaian pada uji coba perorangan terhadap aspek kualitas materi pembelajaran sebesar $89,17 \%$ dan aspek kualitas atau teknis tampilan sebesar 93,33\% dan masing-masing termasuk kategori Sangat Layak. Berdasarkan hasil penilaian pada media pembelajaran interaktif pada uji coba perorangan tidak terdapat saran perbaikan.

Tabel 9. Persentase Rata-Rata Hasil Penilaian Terhadap Media Pembelajaran Interaktif Pada Uji Coba Perorangan

\begin{tabular}{cccc}
\hline No. & Kategorisasi & $\begin{array}{c}\text { Persentase } \\
\text { rata-rata }\end{array}$ & Kriteria \\
\hline & $\begin{array}{l}\text { Aspek kualitas } \\
\text { materi } \\
\text { pembelajaran }\end{array}$ & $89,17 \%$ & $\begin{array}{l}\text { Sangat } \\
\text { Layak }\end{array}$ \\
\hline 1 & $\begin{array}{l}\text { Aspek kualitas } \\
\text { teknis/tampilan }\end{array}$ & $93,33 \%$ & $\begin{array}{l}\text { Sangat } \\
\text { Layak }\end{array}$ \\
\hline & Rata-rata & $91,25 \%$ & $\begin{array}{l}\text { Sangat } \\
\text { Layak }\end{array}$ \\
\hline
\end{tabular}

\section{Analisis Data Hasil Uji Coba Tahap III Uji} Coba Kelompok Kecil.

Tabel 4.39 berikut menunjukkan persentase rata-rata dari hasil penelitian terhadap media pembelajaran interaktif pada uji coba kelompok kecil di SMP Negeri 20 Medan terhadap aspek kualitas materi pembelajaran adalah sebesar 93,31\% dan aspek kualitas teknis atau tampilan sebesar 93,36\% dan masing-masing termasuk kategori Sangat Layak. 
Tabel 10. Persentase Rata-Rata Hasil Penilaian terhadap Interaktif Pada Uji Coba Kelompok Kecil

\begin{tabular}{cccc}
\multicolumn{4}{c}{ Kecil } \\
\hline No. & Kategorisasi & $\begin{array}{c}\text { Persentase } \\
\text { rata-rata }\end{array}$ & Kriteria \\
\hline 1 & $\begin{array}{l}\text { Aspek kualitas } \\
\text { materi } \\
\text { pembelajaran }\end{array}$ & $94,17 \%$ & $\begin{array}{l}\text { Sangat } \\
\text { Layak }\end{array}$ \\
\hline 2 & $\begin{array}{l}\text { Aspek kualitas } \\
\text { teknis/tampilan }\end{array}$ & $93,02 \%$ & $\begin{array}{l}\text { Sangat } \\
\text { Layak }\end{array}$ \\
\hline & Rata-rata & $93,59 \%$ & $\begin{array}{l}\text { Sangat } \\
\text { Layak }\end{array}$ \\
\hline
\end{tabular}

\section{Analisis Data Hasil Uji Coba Tahap IV Uji Coba Lapangan}

Tabel 11. Persentase Rata-Rata Hasil Penilaian Terhadap Media Pembelajaran Interaktif Pada Uji Coba Lapangan

\begin{tabular}{cccc}
\hline No. & Kategorisasi & $\begin{array}{c}\text { Persentase } \\
\text { rata-rata }\end{array}$ & Kriteria \\
\hline 1 & $\begin{array}{l}\text { Aspek kualitas } \\
\text { materi } \\
\text { pembelajaran }\end{array}$ & $93,31 \%$ & $\begin{array}{l}\text { Sangat } \\
\text { Layak }\end{array}$ \\
\hline 2 & $\begin{array}{l}\text { Aspek kualitas } \\
\text { teknis/tampilan }\end{array}$ & $93,36 \%$ & $\begin{array}{l}\text { Sangat } \\
\text { Layak }\end{array}$ \\
\hline & Rata-rata & $93,33 \%$ & $\begin{array}{l}\text { Sangat } \\
\text { Layak }\end{array}$ \\
\hline
\end{tabular}

\section{Pengujian Hipotesis}

a. Hipotesis 1

Berdasarkan penilaian terhadap media pembelajaran interaktif pada uji coba lapangan dengan 80 siswa untuk aspek kualitas materi pembelajaran dan aspek kualitas teknis/tampilan menunjukkan bahwa produk yang dikembangkan Layak digunakan. Rangkuman hasil uji coba lapangan dapat dilihat pada tabel 12 .

Tabel 12. Rangkuman Hasil Uji Coba Lapangan

\begin{tabular}{cccc}
\hline No. & Kategorisasi & $\begin{array}{c}\text { Persentase } \\
\text { rata-rata }\end{array}$ & Kriteria \\
\hline 1 & $\begin{array}{l}\text { Aspek kualitas } \\
\text { materi } \\
\text { pembelajaran }\end{array}$ & $93,31 \%$ & $\begin{array}{l}\text { Sangat } \\
\text { Layak }\end{array}$ \\
\hline 2 & $\begin{array}{l}\text { Aspek kualitas } \\
\text { teknis/tampilan }\end{array}$ & $93,36 \%$ & $\begin{array}{l}\text { Sangat } \\
\text { Layak }\end{array}$ \\
\hline & Rata-rata & $93,33 \%$ & $\begin{array}{l}\text { Sangat } \\
\text { Layak }\end{array}$ \\
\hline
\end{tabular}

Uji t Pre-Test

Setelah uji kelayakan data selesai dilaksanakan, maka selanjutnya dilakukan uji $\mathrm{t}$ pre-test penelitian. Hal ini dilakukan untuk mengetahui apakah terdapat perbedaan kemampuan awal kelas kontrol dan kelas eksperimen dengan menggunakan uji t pre-test.

Berdasarkan hasil perhitungan, diperoleh output $t_{\text {hitung }}$ sebesar 1,422 dan $t_{\text {tabel }}$ sebesar 1,667 pada taraf kepercayaan 95 persen. Maka diperoleh bahwa $t_{\text {hitung }}<t_{\text {tabel }}$ atau 1,422 < 1,667 atau dengan kata lain Ha ditolak. Hal ini menunjukkan bahwa kemampuan awal siswakelas kontrol dan kelas eksperimen adalah cenderung sama dan tidak berbeda secara signifikan.

Uji t Post-Test

Setelah uji $t$ pre-test selesai dilaksanakan, maka selanjutnya dilakukan pengujian hipotesis penelitian dengan menggunakan uji t post-test. Hal ini dilakukan untuk mengetahui apakah ada perbedaan hasil belajar siswa setelah dilakukan perlakuan yang berbeda. Hipotesis penelitian ini adalah sebagai berikut:

Ha: Media pembelajaran yang dikembangkan mampu meningkatkan hasil belajar Ekonomi Ho: Media pembelajaran yang dikembangkan tidak mampu meningkatkan hasil belajar Ekonomi

Berdasarkan hasil perhitungan yang terdapat pada lampiran 4, maka diperoleh data bahwa $t_{\text {hitung }}>t_{\text {tabel }}$ atau 5,785 $>1,667$ atau dengan kata lain $\mathrm{H}_{0}$ ditolak dan $\mathrm{Ha}$ diterima, maka dapatlah disimpulkan bahwa hasil belajar ekonomi siswa yang menggunakan produk media pembelajaran interaktif macromedia flash lebih tinggi dari siswa yang diajar dengan menggunakan buku teks dengan efektifitas penggunaan media interaktif sebesar $63,09 \%$.

\section{PEMBAHASAN}

Produk pengembangan media pembelajaran media pembelajaran interaktif pada mata pelajaran Ekonomi merupakan materi pembelajaran yang telah dikembangkan dengan memperhatikan aspek pembelajaran dan media sebagai prinsip desain pesan pembelajaran. Penelitian pengembangan produk yang dilakukan ini diarahkan untuk menghasilkan suatu produk berupa media pembelajaran interaktif yang digunakan untuk meningkatkan proses pembelajaran maupun kompetensi siswa. Oleh sebab itu proses penelitian ini dilakukan dan diawali dengan (1) studi pendahuluan, (2) kemudian 
mendesain media pembelajaran,

melakukan validasi produk, dan (4) melakukan revisi dan penyempurnaan berdasarkan analisis data validasi dari ahli materi, ahli desain pembelajaran dan ahli rekayasa perangkat lunak yang dilanjutkan dengan uji coba perorangan, uji coba kelompok kecil, dan uji coba lapangan sehingga dihasilkan media pembelajaran yang layak digunakan sesuai dengan karakteristik bidang studi dan siswa sebagai pengguna.

Manfaat dalam penggunaan media pembelajaran interaktif adalah sebagai berikut: (1) materi mudah dipahami karena konsep yang disajikan direncanakan untuk mempermudah siswa dan sistematis, (2) media pembelajaran interaktif memberi kesempatan siswa untuk belajar sesuai degan kecepatan masing-masing individu, (3) belajar lebih cepat dan menarik sehingga tidak menimbulkan kebosanan karena dilengkapi dengan gambar-gambar dan animasi serta soal latihan yang bervariasi, (4) adanya kesempatan dalam menjawab soal pada waktu tes jika jawaban dianggap salah dengan tujuan agar siswa dapat memahami materi yang telah dipelajari, (5) media pembelajaran interaktif ini juga dapat digunakan sebagai alternatif media pembelajaran secara individual.

Dari hasil pengolahan data penelitian yang dilakukan, terdapat perbedaan hasil belajar Ekonomi antara siswa yang dibelajarkan dengan menggunakan media pembelajaran interaktif dan siswa yang dibelajarkan dengan tanpa media pembelajaran interaktif yaitu rata-rata hasil belajar Ekonomi siswa yang dibelajarkan dengan menggunakan media pembelajaran interaktif lebih tinggi dibandingkan dengan siswa yang dibelajarkan tanpa menggunakan media pembelajaran interaktif. Hal ini sesuai dengan hasil penelitian yang relevan oleh Gerlach, Ely (1970), Kemp dan Dayton, Intan (2012), Resien (2010). Maka, media yang telah dihasilkan adalah layak dan efektif untuk digunakan dalam pembelajaran.
Media pembelajaran adalah paket media interaktif di mana di dalamnya terdapat langkah-langkah instruksional yang didesain untuk melibatkan pengguna secara aktif di dalam proses pembelajaran. Seperti yang dikemukakan oleh Sagala (2011:61) pembelajaran interaktif mempunyai dua karakteristik yaitu: (1) dalam proses pembelajaran melibatkan proses mental siswa secara maksimal, bukan hanya menuntut siswa sekedar mencatat, akan tetapi menghendaki aktivitas siswa dalam proses berpikir, (2) dalam pembelajaran membangun suasana dialogis dan proses tanya jawab terus menerus yang diarahkan untuk memperbaiki dan meningkatkan kemampuan siswa untuk memperoleh pengetahuan yang mereka konstruksi sendiri. Keunggulan paling menonjol yang dimiliki media adalah interaktivitas. Interaktivitas secara fisik dalam media pembelajaran bervariasi dari yang paling sederhana hingga yang kompleks.

Media interaktif memungkinkan adanya interaksi, seperti yang dikemukakan oleh Susilana (2009:23) karakteristik terpenting kelompok media ini adalah bahwa siswa tidak hanya memperhatikan media atau objek saja, melainkan juga dituntut untuk berinteraksi selama mengikuti proses pembelajaran. Siswa tidak hanya diajak bicara atau membaca tentang sesuatu masalah tapi juga diajak untuk berkontak secara langsung dengan masalahnya untuk menghasilkan keseragaman pengamatan. Hal ini karena adanya persepsi yang pernah berbeda antara yang pernah melihat, mendengar dan yang mengalami kini dipersatukan dengan melihat, mendengar dan mengalami bersama. Dengan menggunakan media interaktif siswa dapat berinteraksi langsung dengan media sehingga proses pemahaman akan terjadi lebih cepat. Media yang dikemas mengandung unsur pendidikan dan hiburan (edutainment) merupakan kemasan yang memberikan pengalaman belajar yang mengesankan bagi siswa. 
Media pembelajaran ini sangat praktis, karena media ini dapat dibawa oleh siswa dan dapat dipelajari dirumah karena media pembelajaran interaktif tersebut dalam bentuk CD (compact disk) yang ringan. Media pembelajaran ini juga dapat menguji kemampuan dan pemahaman siswa secara langsung melalui tes atau soal-soal latihan yang memiliki durasi waktu dan kunci jawaban yang benar, sehingga siswa dapat mengetahui kesalahan yang telah dilakukan dalam mengerjakan soal latihan tersebut. Media pembelajaran interaktif juga dilengkapi dengan rangkuman yang dapat membantu siswa memperoleh ringkasan materi pelajaran yang dipaparkan. Tanpa media pembelajaran interaktif siswa mendapatkan sumber informasi hanya dari guru yang bersangkutan dengan materi-materi yang ada pada buku, membuat guru menggunakan kontrol pembelajaran dengan aktif, sementara siswa relatif pasif menerima dan mengikuti apa yang disampaikan guru.

\section{PENUTUP}

Hasil validasi dari ahli materi, ahli desain pembelajaran, ahli rekayasa perangkat lunak, tanggapan uji perorangan, uji coba kelompok kecil dan uji coba lapangan terhadap media pembelajaran interaktif mata pelajaran Ekonomi yang dikembangkan menunjukkan bahwa seluruh aspek penilaian media pembelajaran interaktif mata pelajaran yang dikembangkan dengan menggunakan program Macromedia Flash Professional 8.0 secara keseluruhan termasuk dalam kategori "Sangat Layak".

Hasil hipotesis membuktikan bahwa terdapat perbedaan yang sangat signifikan antara hasil belajar siswa yang dibelajarkan dengan media pembelajaran interaktif berbasis economic literacy dengan hasil belajar siswa yang dibelajarkan dengan menggunakan buku teks. Hal ini ditunjukkan dengan hasil pengolahan data diperoleh thitung $>$ ttabel atau 5,785 > 1,667 atau dengan kata lain H0 ditolak dan Ha diterima. Dengan demikian, pengujian hipotesis membuktikan bahwa terdapat perbedaan yang signifikan antara hasil belajar siswa yang dibelajarkan dengan menggunakan media pembelajaran interaktif dan hasil belajar siswa yang dibelajarkan dengan menggunakan media pembelajaran buku teks. Dan pelaksanaan pembelajaran menggunakan media interaktif lebih efektif

\section{DAFTAR PUSTAKA}

Arsyad, A.2002. Media Pembelajaran, Jakarta : PT Raja Grafindo

Persada.

Barbara, B. 1994. Teknologi Pembelajaran: Defenisi dan Kawasannya. Jakarta: Percetakan Universitas Negeri Jakarta.

Borg, W. \&V Gall, M.D. 2005. Applying Educational Research (5th Ed). USA.

Budiningsih, Asri, 2003. Desain Pesan Pembelajaran. Yogyakarta: Fakultas Ilmu Pendidikan Universitas Negeri Yogyakarta.

Case, Fair, 2006. Prinsip-prinsip Ekonomi Jilid I. Jakarta: Erlangga.

Dahar, Ratna Wilis, 2006. Teori-teori Balajar dan Pembelajaran. Jakarta: Erlangga

Daryanto, 2012. Media Pembelajaran. Bandung: Sarana Tutorial Nurani Sejahtera

D. Gall, Meredith, P. Gall, Joyce \& R. Borg, Walter, 2003. Educational Research An Introduction Seventh Edition. New York: Pearson Education, Inc.

Dick, Walter, Carey, Lou \& O. Carey, James, 2005. The Systematic Design of Instruction Sixth Edition. New York: Pearson Education, Inc.

Dimyati, Mudjiono, 2013. Belajar dan Pembelajaran. Jakarta: Rineka Cipta.

Gagné, R.M.;Briggs, L.J \& Wager, W.W. 1992. Principles of Instruction Design. New York: Saunders College Publishing.

Geralch, V.G dan Ely, D.P, 1971. Teaching and Media. A Systematic Approach. Englewood Cliffs: Prentice-Hall, Inc.

Hakim, L, 2004. Cara Ampuh Menguasai Macromedia Flash Professional 8.0. Jakarta: PT Elex Media Komputindo.

Hamalik, Oemar, 2006. Media Pendidikan. Bandung: PT. Citra Aditya Bakti.

Hamid, A, 2009. Teori Belajar dan Pembelajaran. Bandung: Alfabeta.

Heinich, Robert, et. Al, 2011. Instructional Media And Technologies For Learning (5th Edition). New Jersey: A Simon \& Schuster Company Angelwood Cliffs. 
Mankiw, dkk, 2013. Pengantar Ekonomi Mikro. Jakarta: Salemba Empat.

Miarso, 2011. Menyemai Benih Teknologi Pendidikan. Jakarta: Prenada Media.

Rusman, 2013. Belajar dan Pembelajaran Berbasis Komputer: Mengem bangkan Profesionalisme Guru Abad 21. Bandung: Alfabeta.

Sagala, S, 2011. Konsep dan Makna Pembelajaran. Bandung: Alfabeta.

Sapriya, 2011. Pendidikan IPS. Bandung: Remaja Rosdakarya.

Setijadi, 1986. Defenisi Teknologi Pendidikan: Satuan Tugas Defenisi Dan Terminologi AECT. Jakarta: CV. Rajawali.

Siregar, Eveline, 2010. Teori Belajar dan Pembelajaran. Bogor: Ghalia Indonesia

Slavin, R.E, 2000. Educational Pscychology: Theory and Practice. 6th Edition.

Soetjipto, R, 1985. Ilmu Pengetahuan Sosial. Jakarta: Percetakan Negara RI.

Soeharno, 2006. Teori Ekonomi. Yogyakrta: Andi Offset

Sudjana, Nana, 2010. Penilaian Hasil Proses Belajar Mengajar. Bandung: Remaja Rosdakarya.
Surya, Mohammad, 2003. Psikologi Pembelajaran dan Pengajaran. Jakarta: Pustaka Bani Quraisy.

Supardi, 2011. Dasar-dasar Ilmu Sosial. Yogyakarta: Ombak.

Suryosubroto, B, 2009. Proses Belajar Mengajar Di Sekolah. Jakarta: PT. Rineka Cipta.

Susilana, Rudi, 2009. Media Pembelajaran: Hakikat, Pengembangan, Pemanfaatan dan Penilaian. Bandung: Wacana Prima.

Syah, Muhibbin, 2012. Psikologi Belajar. Raja Grafindo Persada.

Trianto, 2007. Model-model Pembelajaran Inovatif Berorientasi Konstruktivistik. Surabaya: Prestasi Pustaka Publisher 2009. Mendesain Model Pembelajaran Inovatif-Progresif. Jakarta Charisma Putra Utama.

Tu'u, Tulus, 2004. Peran Disiplin pada Perilaku dan Prestasi Siswa. Jakarta: Gramedia Grasindo.

Wiyani, A, Novan, 2013. Desain Pembelajaran Pendidikan: Tata Rancangan Pembelajaran Menuju Pencapaian Kompetensi. Yogyakarta: Ar-Ruzz Media. 